\title{
Stability of Viable Counts of Lactic Acid Bacteria during Storage of Goat Milk Soft Cheese
}

\author{
WINIATI PUDJI RAHAYU*, FERI KUSNANDAR, AND \\ WIDYA EKA PRAYITNO \\ Department of Food Science and Technology, Faculty of Agricultural Engineering and Technology, \\ Institut Pertanian Bogor, Darmaga Campus, Bogor 16680, Indonesia
}

\begin{abstract}
The use of goat milk is limited in Indonesia due to lack of good milking practices resulted in disliked goaty smell. One of the method to eliminate this off flavor is by processing the goat milk into soft cheese. The aim of this research was to study the stability of viable starter lactic acid bacteria cultures (Lactobacillus acidophilus FNCC-0051 and L. casei FNCC-0090) during storage of goat milk soft cheese. Three batches of goat milk soft cheeses were produced with different starter cultures L. acidophilus FNCC-0051 (5.0 × $\left.10^{6} \mathrm{cfu} \mathrm{mL}^{-1}\right)$; L. casei FNCC-0090 $\left(5.0 \times 10^{6} \mathrm{cfu} \mathrm{mL}^{-1}\right)$; and the mixture of L. acidophilus FNCC-0051 $\left(2.5 \times 10^{6} \mathrm{cfu} \mathrm{mL}^{-1}\right)$ and L. casei FNCC-0090 $\left(2.5 \times 10^{6} \mathrm{cfu} \mathrm{mL}^{-1}\right)$. The goat milk cheeses had white color and soft. The viable lactic acid bacteria in the goat milk soft cheese reached $10^{9} \mathrm{cfu} \mathrm{g}^{-1}$, which was stable for 8 weeks at $5^{\circ} \mathrm{C}$. Panelists liked goat milk soft cheeses, especially in term of its aroma. The specific aroma produced could mask the disliked goaty smell.

Key words: goat milk, soft cheese, starter lactic acid bacteria

Susu kambing di Indonesia masih terbatas pemanfaatannya karena bau kambing yang kurang disukai, terutama akibat proses pemerahan yang kurang baik. Salah satu cara untuk mengurangi aroma yang kurang disukai tersebut ialah dengan mengolahnya menjadi keju lunak. Penelitian ini bertujuan menentukan stabilitas kultur starter bakteri asam laktat (Lactobacillus acidophilus FNCC-0051 dan L. casei FNCC-0090) selama penyimpanan keju lunak susu kambing. Keju lunak diproduksi menggunakan tiga kultur starter yang berbeda, yaitu L. acidophilus FNCC-0051 (5.0 x $\left.10^{6} \mathrm{cfu} \mathrm{mL}^{-1}\right)$; L. casei FNCC-0090 (5.0 x $\left.10^{6} \mathrm{cfu} \mathrm{mL}^{-1}\right)$; dan campuran L. acidophilus FNCC-0051 (2.5 x $\left.10^{6} \mathrm{cfu} \mathrm{mL}^{-1}\right)$ dan L. casei FNCC-0090 (2.5 x $\left.10^{6} \mathrm{cfu} \mathrm{mL}^{-1}\right)$. Keju yang dihasilkan berwarna putih dan bertekstur lunak. Jumlah bakteri asam laktat pada keju lunak susu kambing mencapai $10^{9} \mathrm{cfu} \mathrm{g}^{-1}$ dan relatif stabil selama penyimpanan 8 minggu pada suhu $5^{\circ} \mathrm{C}$. Para panelis menyukai aroma keju lunak susu kambing karena mampu menutupi aroma susu kambing yang kurang disukai.
\end{abstract}

Kata kunci: keju lunak, starter bakteri asam laktat, susu kambing

The goat milk production has steadily increased in Indonesia since 2000; however, its usage as a healthy drink is limited due to its unpleasant smell. The goat milk is usually consumed by children and adults. Goat milk provides essential nutrients, such as minerals, vitamins and easily digestible proteins with balanced amino acid profile which is important in supporting most body functions (Silanikove et al. 2010). However, many people does not like the goaty smell of goat milk resulted in the low consumption of goat milk. The goaty smell comes from medium-chain fatty acid (caproic, caprylic and capric acids) in goat milk fat (Silanikove et al. 2010).

In Turkey, Greece, and France, goat milk cheese has been processed commercially. In recent years, cheese becomes popular in Indonesia and it is mainly consumed as a food complement. Most of cheeses in Indonesia are imported products, particularly, natural cheeses made from cow's milk. Goat milk is potential to be processed into cheese products in order to promote the added value of goat milk.

Recently, world-wide interest on functional foods containing probiotic bacteria for health promotion and

*Corresponding author, Phone/Fax:+62-251-8626725, E-mail: wini_a@hotmail.com disease prevention has increased remarkably (Vankerckhoven et al. 2008). Cheese product has been developed as a vehicle for probiotic bacteria. In an effort to extend the probiotic product range, a small number of researchers and companies have manufactured cheeses with a high viable count of probiotic cultures. Cheese containing probiotic is a functional food.

Therefore, this study reports the stability of Lactobacillus acidophilus FNCC-0051 and L. casei FNCC-0090 as starter cultures in goat milk soft cheese during storage, and goat milk soft cheese's chemical and sensory state.

\section{MATERIALS AND METHODS}

Starter Cultures. The commercial L. acidophilus FNCC-0051 and L. casei FNCC-0090 were used as cheese starter cultures. The strains were activated by growing at $37{ }^{\circ} \mathrm{C}$ overnight in a sterile de Mann's Rogossa Sharpe Broth (MRSB). The goat milk was heated at $85^{\circ} \mathrm{C}$ for $30 \mathrm{~min}$. The two lactic acid bacteria $\left(\mathrm{mL} \mathrm{L}^{-1}\right)$ were inoculated into goat milk then incubated at $37^{\circ} \mathrm{C}$ for $6 \mathrm{~h}$.

Goat Milk Soft Cheese Production. Goat milk soft cheese was made from heated Ettawa goat milk $\left(85^{\circ} \mathrm{C}\right.$ 
for $30 \mathrm{~min})$ and $5 \%(\mathrm{v} / \mathrm{v})$ inoculums of the single or mixed strain starter culture was added. Three batches of goat milk soft cheeses were produced with different starter cultures: L. acidophilus FNCC-0051 $\left(5.0 \times 10^{6}\right.$ cfu $\left.\mathrm{mL}^{-1}\right)$ (batch 1), L. casei FNCC-0090 $\left(5.0 \times 10^{6} \mathrm{cfu}\right.$ $\mathrm{mL}^{-1}$ ) (batch 2), and the mixture of $L$. acidophilus FNCC-0051 $\left(2.5 \times 10^{6} \mathrm{cfu} \mathrm{mL}^{-1}\right)$ and L. casei FNCC$0090\left(2.5 \times 10^{6} \mathrm{cfu} \mathrm{mL}^{-1}\right)$ (batch 3). Each batch was made in two replicates. The use of lactic acid bacteria reduced the $\mathrm{pH}$ which affected the coagulation time. Heated goat milk was inoculated by starter culture and was incubated at $37^{\circ} \mathrm{C}$ for $6 \mathrm{~h}$. The matured milk was added with liquid rennet $\left(0.06 \mathrm{~mL} \mathrm{~L}^{-1}\right.$ of milk) and it was coagulated after $2 \mathrm{~h}$. Coagulated milk (curd) was cutted with cheeseharp into cube form $(1 \times 1 \times 1 \mathrm{~cm})$. The curds were cooked at $40{ }^{\circ} \mathrm{C}$ for $30 \mathrm{~min}$. The whey was drained and the fresh cheese was salted $(2 \%, w / w)$. The soft cheese was packed in plastic bag and was stored at $5^{\circ} \mathrm{C}$ for 8 weeks.

pH Measurement. The $\mathrm{pH}$ change of raw milk, maturated milk, curd, whey, and fresh cheese were measured. The $\mathrm{pH}$ of soft cheese was also measured during 8 weeks storage period. The $\mathrm{pH}$ was measured according to the standard procedure of AOAC (1995). $10 \mathrm{~mL}$ of goat milk and whey were measured directly by $\mathrm{pH}$ meter (Thermo). Ten gram of curd and fresh cheese were diluted in $10 \mathrm{~mL}$ of aquades before measurement.

Viability of Lactic Acid Bacteria during Processing and Storage of Soft Cheese at $5{ }^{\circ} \mathrm{C}$. To count the viability of starter culture bacteria, twenty gram samples of maturated milk, curd, whey, as well as soft cheese were collected during production. Twenty gram of cheese samples were collected each week at first month and every two weeks at second month to find out the stability of the starter lactic acid bacteria during storage. The viable lactic acid bacteria during processing was only counted for the first batch (L. acidophilus FNCC-0051) while during storage was counted for all batches (L. acidophilus FNCC-0051, L. casei FNCC-0090, and the mixture of L. acidophilus FNCC-0051 and L. casei FNCC-0090). These experiments were carried out in two replicates. The enumeration of the viable lactic acid bacteria was carried out as described by Burns et al. 2008. Twenty gram of cheese was placed in $180 \mathrm{~mL}$ of $2 \%$ $(\mathrm{w} / \mathrm{v})$ sodium citrate sterile solution. The cheese sample was crushed to bits by stomacher. Decimal dilutions of the homogenates were made in $0.0043 \%$ (w/v) $\mathrm{KH}_{2} \mathrm{PO}_{4}$ solution. $1 \mathrm{~mL}$ of maturated milk and whey were directly diluted into $9 \mathrm{~mL}$ of $0.0043 \%$ (w/v) $\mathrm{KH}_{2} \mathrm{PO}_{4}$ solution. Appropriate dilutions were pour-plated. Lactic acid bacteria were enumerated $\left(37^{\circ} \mathrm{C}, 48 \mathrm{~h}\right)$ on de Mann's Rogossa Sharpe Agar (MRSA).

Sensory Quality Test. The acceptance of goat soft cheese was evaluated according to the procedure of Drake' (2007). The cheeses were evaluated based on their aroma, taste, and aftertaste by nine trained panelists. A commercial goat milk cheese was tested to know the position of the produced cheese. The soft cheese samples were placed in saucer coded by threedigit random numbers. Coffee powder and water were served in between to neutralize the sense of smell.

Sensory evaluation used $0-15 \mathrm{~cm}$-line scale $(0=$ dislike intensely and $15=$ like extremely). The panelis scored on the line scale. The scores were obtained by measurement the length from $0 \mathrm{~cm}$ to the signed mark. Then, the scores were analysed by ANOVA.

Chemical Composition and Trace Element Analyses. Cheese which has no syneresis during 8weeks storage was used for chemical and trace element analyses. The chemical analyses were moisture content (gravimetric method, BSN 1992a), ash (BSN 1992a), fat (soxhlet method, BSN 1992a), crude protein (Kjeldahl method, AOAC 1995), and total carbohydrate (by difference). The trace element analyses were done using AAS included $\mathrm{As}, \mathrm{Pb}, \mathrm{Cu}, \mathrm{Zn}, \mathrm{Hg}$, and Sn (SNI 01-2980-1992 method, BSN 1992b; 1998a; 1998b).

\section{RESULTS}

pH Value and Stability of Viable Lactic Acid Bacteria during Production and Storage at $5{ }^{\circ} \mathrm{C}$. The $\mathrm{pH}$ value and viable counts of lactic acid bacteria during cheese production are shown in Table 1. $\mathrm{pH}$ reduction was observed during cheese production. The viable count of lactic acid bacteria at cultured milk, curd and whey were $10^{8} \mathrm{cfu} \mathrm{g}^{-1}$ and it increased one $\log$ cycle in soft cheese (Table 1). $\mathrm{pH}$ value of soft cheese significantly decreased during storage at $5{ }^{\circ} \mathrm{C}(\mathrm{p}<0.05)$. The lowest $\mathrm{pH}$ occurred after 8 weeks storage at $5{ }^{\circ} \mathrm{C}$ was 4.37 . Viable counts of lactic acid bacteria was stable during storage, which remained constant at $10^{9} \mathrm{cfu} \mathrm{g}^{-1}$ after 8 -weeks storage at $5{ }^{\circ} \mathrm{C}$ (Fig 1).

Sensory Evaluation. The average sensory scores by trained panelists are presented in Table 2 . There was significant $(p<0.05)$ difference in aroma score between the experimental goat milk soft cheese and commercial goat milk soft cheese. Goat milk soft cheese had better aroma (11.33-11.97: like fairly well-like very well) than commercial goat milk soft cheese (6.66: like slighly). Moreover, no significant ( $\mathrm{p}>0.05$ ) difference in taste and aftertaste score were observed between the cheeses. 


\section{Chemical Composition and Trace Element} Content. The selected goat milk soft cheese originated from batch 1, cultured with L. acidophilus FNCC-0051 was analyzed its chemical composition and trace element content. The chemical composition of the cheese is shown in Table 3. The experimental cheese had lower fat and protein content as compared to commercial cheeses. Trace element

Table $1 \mathrm{pH}$ values and total Lactobacillus acidophilus FCNN-0051 in goat milk soft cheese during production

\begin{tabular}{lll}
\hline Sample & $\mathrm{pH}$ & $\begin{array}{l}\text { L.acidophilus FCNN-0051 } \\
\left(\log _{10} \mathrm{cfu}^{-1}\right)\end{array}$ \\
\hline Heated raw & & \\
milk & $6.60 \pm 0.00$ & na \\
Cultured milk & $6.30 \pm 0.00$ & $8.45 \pm 0.12^{*}$ \\
Curd & $6.12 \pm 0.02$ & $8.85 \pm 0.17$ \\
Whey & $6.15 \pm 0.07$ & $8.47 \pm 0.09$ \\
Soft cheese & $5.70 \pm 0.00$ & $9.94 \pm 0.09$ \\
\hline
\end{tabular}

na: no available data

*cfu $\mathrm{mL}^{-1}$ content of goat milk soft cheese is shown in Table 4. $\mathrm{As}, \mathrm{Pb}, \mathrm{Hg}$, and $\mathrm{Sn}$ level were below limit of detection (LoD) of instrument, indicating the cheese was free from heavy metals. However $\mathrm{Cu}$ and $\mathrm{Zn}$ were detected in the goat milk soft cheese. $\mathrm{Cu}$ and $\mathrm{Zn}$ as essential trace elements for body function were present at 13.53 and $21.56 \mathrm{ppm}$, respectively.

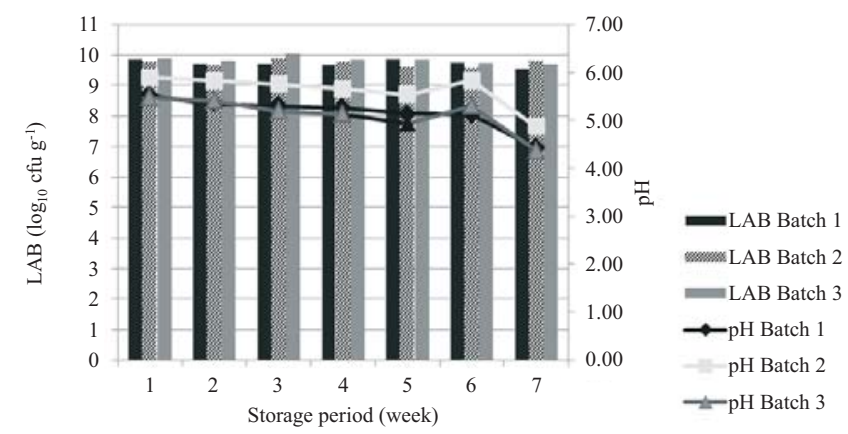

Fig 1 Total viable lactic acid bacteria and $\mathrm{pH}$ in goat milk soft cheese with different starter culture during 8 -week storage at $5^{\circ} \mathrm{C}$.

Table 2 Sensory properties* of goat milk soft cheese with different LAB starter culture

\begin{tabular}{|c|c|c|c|}
\hline Samples & Aroma & Taste & After taste \\
\hline Cheese with L.acidophilus FCNN-0051 & $11.40 \pm 2.38^{\text {a) }}$ & $10.36 \pm 2.50^{\mathrm{a})}$ & $9.49 \pm 3.36^{\text {a) }}$ \\
\hline Cheese with L. casei FNCC-0090 & $11.97 \pm 2.13^{\text {a) }}$ & $10.42 \pm 2.95^{\mathrm{a})}$ & $8.56 \pm 2.82^{\text {a) }}$ \\
\hline $\begin{array}{l}\text { Cheese with L.acidophilus FCNN-0051 and } L \text {. } \\
\text { casei FNCC-0090 }\end{array}$ & $11.33 \pm 2.89^{\text {a) }}$ & $10.37 \pm 2.69^{\mathrm{a})}$ & $8.92 \pm 3.50^{\text {a) }}$ \\
\hline Commercial feta cheese & $6.66 \pm 4.47^{\mathrm{b})}$ & $8.54 \pm 4.09^{\text {a) }}$ & $5.70 \pm 3.06^{\mathrm{a})}$ \\
\hline
\end{tabular}

*: $0=$ dislike intensely and $15=$ like extremely

$\stackrel{a, b}{a}$ different letters in the same column indicate significant differences $(p<0.05)$

Table 3 Nutritional composition of goat milk soft cheese compared to other cheeses

\begin{tabular}{|c|c|c|c|c|c|}
\hline \multirow{2}{*}{ Component (\%) } & \multirow{2}{*}{$\begin{array}{l}\text { Experimental goat } \\
\text { milk soft cheese } \\
\text { L.acidophilus FCNN-0051 }\end{array}$} & \multicolumn{3}{|c|}{ Commercial goat milk cheese ${ }^{\mathrm{a}}$} & \multirow{2}{*}{$\mathrm{SNI}^{\mathrm{b}}$} \\
\hline & & Fresh soft & Feta & Cheddar & \\
\hline Moisture & $52.00 \pm 0.67$ & $59.80 \pm 6.81$ & $52.30 \pm 1.21$ & $41.70 \pm 1.76$ & $\max .45 .0$ \\
\hline Ash & $3.17 \pm 0.05$ & $1.74 \pm 0.97$ & $4.30 \pm 0.27$ & $3.60 \pm 0.13$ & $\max . \quad 5.5$ \\
\hline Fat & $23.49 \pm 0.68$ & $22.50 \pm 4.37$ & $25.30 \pm 1.06$ & $26.60 \pm 1.13$ & $\min .25 .0$ \\
\hline Protein & $15.67 \pm 0.03$ & $18.90 \pm 5.26$ & $25.10 \pm 1.56$ & $30.30 \pm 0.56$ & $\min .19 .5$ \\
\hline
\end{tabular}

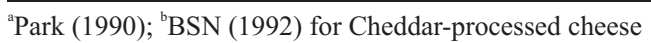

Table 4 Trace element content of goat milk soft cheese compared to other cheese

\begin{tabular}{|c|c|c|c|c|}
\hline \multirow{2}{*}{ Trace elements (ppm) } & \multirow{2}{*}{$\begin{array}{l}\text { Goat milk soft cheese } \\
\text { L.acidophilus FCNN-0051 }\end{array}$} & \multicolumn{2}{|c|}{ Cheeses } & \multirow{2}{*}{$\mathrm{SNI}^{\mathrm{c}}$} \\
\hline & & Goat milk cheese $^{\mathrm{a}}$ & Cow milk cheese $^{\mathrm{b}}$ & \\
\hline As & $<0.003$ & na & na & $\max . \quad 0.1$ \\
\hline $\mathrm{Pb}$ & $<0.01$ & na & na & $\max . \quad 0.3$ \\
\hline $\mathrm{Cu}$ & 13.53 & 6.46 & na & $\max .20 .0$ \\
\hline $\mathrm{Zn}$ & 21.6 & 15.5 & 28.1 & $\max .40 .0$ \\
\hline $\mathrm{Hg}$ & $<0.0002$ & na & 0.001 & $\max .0 .03$ \\
\hline $\mathrm{Sn}$ & $<0.01$ & na & na & $\max .40 .01$ \\
\hline
\end{tabular}

${ }^{a}$ Park (1990); ${ }^{\text {b}}$ Gambelli et al. (1999); ${ }^{\mathrm{B}} \mathrm{BSN}(1992)$

na: no available data 


\section{DISCUSSION}

In this research, $L$. acidophilus $\mathrm{FCNN}-0051$ and L. casei FCNN-0090 were used as starter cultures for manufacturing cheese. Vinderola et al. 2009; Ong and Shah 2009 reported that L. acidophilus A3 as well as L acidophilus 4962, L. acidophilus L10 and L. casei 279, L. casei L26 were able to use for manufacturing cheese. The decrease of $\mathrm{pH}$ value was observed during cheese production due to metabolic activity of starter culture in fermenting lactose during growing, shown by higher population of viable lactic acid bacteria. The milk was fermented for 6 hours and $\mathrm{pH}$ value was 6.3. Chymosin, which is the most important enzyme in rennet, was activated at $\mathrm{pH}$ 6.3. The enzyme helped in hydrolizing peptide bonds, particularly the Phe-Met bond between residues 105 and 106 of $\kappa$ casein, which triggered protein coagulation (Egito et al. 2007).

The goat milk soft cheeses had white color, soft, and crumbly texture. Goat milk is reported to form a finer curd than cow milk following acidification, which mimics the conditions in the stomach, suggesting it would be more readily digested. During cooking, the temperature of the cheese curds was $40{ }^{\circ} \mathrm{C} . L$. acidophilus have optimal growth temperatures of $35-45{ }^{\circ} \mathrm{C}$, while Lactobacillus casei was able to grow through a wide range of temperatures $\left(15-45^{\circ} \mathrm{C}\right)$ (Randazzo et al. 2004). In suitable temperature, metabolism of viable lactic acid bacteria was optimized. In soft cheese, $\mathrm{pH}$ change was attributed to the increase of metabolic activities of bacteria. The culture was in better environmental conditions to multiply in cultured milk affected lower $\mathrm{pH}$ value in soft cheese.

The number of viable lactic acid bacteria $\left(10^{9} \mathrm{cfu}\right.$ $\mathrm{g}^{-1}$ ) was relatively stable during 8 -weeks storage at 5 ${ }^{\circ} \mathrm{C}$, indicating that storage at $5{ }^{\circ} \mathrm{C}$ did not promote metabolic activity of LAB in cheese. Soft cheese goat milk is a suitable food for the delivery of $L$. acidophilus FCNN-0051 and L. casei FCNN-0090 since the culture remained viable. Similar result was reported by Ong et al. (2006) at Cheddar cheese inoculated with $L$. acidophilus 4962, L. casei 279, Bifidobacterium longum 1941 as well as inoculated with $L$. acidophilus LAFTI $^{\circledR}$ L10, L. paracasei LAFTI $^{\circledR}$ L26, B. lactis LAFTI $^{\circledR}$ B94, survived during manufacturing process and maintained their viability of $>3.2 \times 10^{7} \mathrm{cfu} \mathrm{g}^{-1}$ at the end of ripening ( 6 months, $\left.4{ }^{\circ} \mathrm{C}\right)$. Ong and Shah (2009) also showed the stability of viable counts of L. acidophilus 4962 during ripening of cheddar cheese, which was remained viable $\left(>10^{8} \mathrm{cfu} \mathrm{g}^{-1}\right)$ at the end of 24 weeks and their viability was not affected by the ripening temperatures $\left(4\right.$ and $\left.8^{\circ} \mathrm{C}\right)$.
Sensory properties of goat milk cheese are an important factor for consumer in accepting and for producer in manufacturing and marketing the products (Ribeiro and Ribeiro 2010). In general, goat milk cheese has brighter white color than cow milk cheese due to the low $\beta$-carotene in goat milk (RaynalLjutovac et al. 2008). Lack of the pressing process led to the texture of cheese becomes soft and crumble. The pressing is needed (except for soft cheeses) to achieve form a rind surface.

The goat milk soft cheese was accepted by panelist. Panelist gave better score to the experimental goat milk soft cheese from batch 1 , batch 2 , and batch 3 than the commercial one, especially in term of its aroma. The goat milk soft cheese had sour aroma that covered the goaty smell. Molecular weight of lactic acid (90.08 $\mathrm{g} \mathrm{mol}^{-1}$ ) which is responsible for sour aroma is lower that caproic acid $\left(116.1 \mathrm{~g} \mathrm{~mol}^{-1}\right)$, caprylic acid $(144.2 \mathrm{~g}$ $\left.\mathrm{mol}^{-1}\right)$, and capric acid (172.3 $\left.\mathrm{g} \mathrm{mol}^{-1}\right)$ which are responsible for goaty smell, so that easily reach the olfactory epithelium. Smit et al. (2005) described that flavour compounds in cheese arise from the action of enzymes from rennet, milk, the starter and non-starter lactic acid bacteria, together with non-enzymatic conversions. Moisture content of the cheese was within the range of semisoft or semihard cheese $(45-55 \%)$. Fat and protein composition (\%) of experimental goat milk soft cheese were lower than commercial fresh soft nor feta cheese due to its milk composition. Heavy metals content ( $\mathrm{As}, \mathrm{Pb}, \mathrm{Hg}$, and $\mathrm{Sn}$ ) of goat milk soft cheese were below the LoD of AAS, indicating the cheese was free from toxic substances, while $\mathrm{Cu}$ and $\mathrm{Zn}$ as essential trace elements for body function were present at 13.53 and $21.56 \mathrm{ppm}$, respectively.

\section{REFERENCES}

AOAC. 1995. Official method of analysis of the AOAC. $14^{\text {th }}$ ed. Arlington, Virginia: AOAC

Badan Standardisasi Nasional.1992a. Keju cedar olahan [Cheddar cheeses processed].SNI 01-2980-1992. Jakarta(ID): BSN.

Badan Standardisasi Nasional. 1992b. Cara uji makanan dan minuman [Food and beverage analyzed]. SNI 01-2891-1992. Jakarta (ID): BSN.

Badan Standardisasi Nasional. 1998a. Cara uji cemaran arsen dalam makanan [Arsenic contamination food analyzed]. SNI 01-4866-1998. Jakarta (ID): BSN.

Badan Standardisasi Nasional. 1998b. Cara uji cemaran logam dalam makanan [Metal contamination food analyzed]. SNI 01-2896-1998. Jakarta (ID): BSN

Burns P, Patrignani F, Serrazanetti D, Vinderola GC, Reinheimer JA, Lanciotti R, Guerzoni ME. 2008. Probiotic crescenza cheese containing Lactobacillus casei and Lactobacillus acidophilus manufactured with high-pressure homogenized milk. J Dairy Sci. 91(2):500-512. doi:10.3168/jds.2007-0516

Drake' MA. 2007. Invited review: sensory analysis of dairy foods. J Dairy Sci. 90(11):4925-4937. doi:10.3168/jds.2007-0332.

Egito AS, Girardet JM, Laguna LE, Poirson C, Mollé D, Miclo L, Humbert G, Gaillard JL. 2007. Milk-clotting activity of enzyme extracts from 
sunflower and albizia seeds and specific hydrolysis of bovine $K$-casein. Int Dairy J. 17(7):816-825. doi:10.1016/j.idairyj.2006.09.012

Gambelli L, Belloni P, Ingrao G, Pizzoferrato L, Santaroni GP. 1999. Minerals and trace elements in some Italian dairy products. J Food CompAnal. 12(1):27-35. doi:10.1006/jfca.1998.0802.

Ong L, Henriksson A, Shah NP. 2006. Development of probiotic cheddar cheese containing Lactobacillus acidophilus, Lb. casei, Lb. paracasei and Bifidobacterium spp. and the influence of these bacteria on proteolytic patterns and production of organic acid. Int Dairy J. 16(5):446456. doi:10.1016/j.idairyj.2005.05.008.

Ong L, Shah NP. 2009. Probiotic cheddar cheese: influence of ripening temperatures on survival of probiotic microorganism, cheese composition and sensory organic acid profiles. J Food Sci Tech. 42(7):1260-1268. doi: 10.1016/j.1wt.2009.01.011.

Park YW. 1990. Nutrient profiles of commercial goat milk cheeses manufactured in the United States. J Dairy Sci. 73(11):3059-3067. doi:10.3168/jds.S0022-0302(90)78993-X.

Randazzo CL, Restuccia C, Romano AD, Caggia C. 2004. Lactobacillus casei, dominant species in naturally fermented Sicilian green olives. Int J Food Microbiol. 90(1):9-14. doi:10.1016/SO1681605(3)00159-4.
Raynal-Ljutovac K, Lagriffoul G, Paccard P, Guillet I, Chilliard Y. 2008. Composition of goat and sheep milk products: an update. Small Rum Res. 79(1):57-72. doi.10.1016/j.smallrumres.2008.07.009.

Ribeiro AC, Ribeiro SDA. 2010. Specialty products made from goat milk. Small Rum Res. 89(2):225-233. doi:10.1016/j.smallrumres.2009.12.048.

Silanikove N, Leitner G, Merin U, Prosser CG. 2010. Recent advances in exploiting goat's milk: Quality, safety and production aspects. Small Rum Res. 89(2):110124. doi:10.1016/j.smallrumres.2009.12.033.

Smit G, Smit BA, Engels WJM. 2005. Flavour formation by lactic acid bacteria and biochemical flavour profiling of cheese products. FEMS Microbiol Rev. 29(3):591-610. doi: 10.1016/j.fmrre.2005.04.002.

Vankerckhoven V, Huys G, Vancanneyt M, Vael C, Klare I, Romond MB, Entenza JM, Moreillon P, Wind RD, Knol J, Wiertz E, Pot B, Vaughan EE, Kahlmenter G, Goossens H. 2008. Biosafety assessment of probiotics used for human consumption: recommendation from the EU-PROSAFE project. Trends in Food Sci Tech. 19(2):102-114. doi:10.10.16/j.tifs.2007.07.013.

Vinderola G, Prosello W, Molinari F, Ghiberto D, Reinheimer J. 2009. Growth of Lactobacillus paracasei A13 in Argentinian probiotic cheese and its impact on the characteristics of the product. Int J Food Microbiol. 135(2):171-174. doi:10.1016/j.ijfoodmicro.2009.08.021. 